\title{
Improving Students' Initial Reading Skills Through Big Book media in Class IB of MI Muhammadiyah Kedung Jampang
}

\author{
${ }^{1 \text { st }}$ Supriatna, \\ Jakarta State University
}

\author{
${ }^{2 n d}$ Emzir, \\ Jakarta State University
}

\author{
${ }^{3 r d}$ YumnaRasyid \\ Jakarta State University
}

\begin{abstract}
This Classroom Action Research aimed to improve the students' initial reading skill through the big book media on the theme of Natural Events in the first grade of Elementary School. This study consisted of two cycles. Each cycle consisted of two meetings. The research design used in this study was Kemmis\&Mc Taggart model with 4 stages, namely planning, implementing, observing and reflecting. Subject in this study was 24 students of class IB of this school consisting of 9 female students and 15 male students. Instruments used for collecting the data in this study were the initial reading skill assessment sheets supported by the teacher activity observation sheets, and the student activity observation sheets. The success indicator in this study was a very good value of the beginning reading skill of the students obtaining the learning mastery value of 70. The results of the study showed that the big book media can improve students' initial reading skills. It was proven by the data showing the increasing value of students' learning mastery in reading skills using this media. Students' average value was 2.42 with sufficient criteria in cycle $I$ and 3.4 with very good criteria in cycle II. It can be concluded that this media can improve students' reading skills.
\end{abstract}

Keywords: Big Book, Initial Reading.

\section{INTRODUCTION}

Language is the most important capital for humans, because language is a communication tool used every day.Language development in elementary school is strengthened by the provision of Indonesian Language learning. BSNP (NationalEducationStandards Agency)in Susanto (2015: 245) states that Indonesian Language learning is createdto improve students' ability to communicate properly and correctly, both verbally and in writing.

Reading skill is one of the most important aspects of languagetaught to students.Students in grades I and II of elementary school learn initial reading skills while in grades III, IV, V, and VI they learn reading to comprehend the content of a text.

There are several technical aspects of initial reading which must be mastered by students such as accuracy in the pronunciation, intonation, clarity, and the smoothness while reading.These aspects make initial reading become a skill that underlies others. Besides, at this stage, the lower class students begin to recognize letters, sounds, words, syllables, and sentences even in simple forms. Thus initial reading can help students understand a reading text.

Studentinitial reading skill is influenced by various factors; one of them is learning activity at school.The implementation of the 2013 thematicbased curriculum requires teachers to be more creative in learning activity.Teachers are always trying to improve the reading skill of learners, but sometimes there are still many students who have difficulty in reading.

Based on preliminary observationsand the results of interviews with the class teacher of IB at MI MuhammadiyahKedungJampang, it is knownthat students' initial reading skill is still low. It is proved by students who still imitated sentences read by the teacher without paying attention to the intonation and pronunciation.Students who had not been able to read fluently just remembered the teacher's words without paying attention to the set of letters.

The low initial students' reading skills can be shown from the daily assignment of the reading aspect in table 1.1 below:

\section{TabO11. Daily Assignment Score}

\begin{tabular}{|c|c|c|c|}
\hline No & $\begin{array}{c}\text { Score } \\
\text { Interval }\end{array}$ & Category & $\begin{array}{c}\text { Frequency } \\
\text { of students }\end{array}$ \\
\hline 1. & $85-100$ & Very good & 9 \\
\hline 2. & $70-84$ & Good & 4 \\
\hline 3. & $55-69$ & Moderate & 6 \\
\hline 4. & $40-54$ & Poor & 5 \\
\hline \multicolumn{3}{|c|}{ Total } & 24 \\
\hline
\end{tabular}

Students' low score was also due to the lack of creativity of class teacher when teaching.The teacher just gavelecture, question and answer session, and tasks so that learners tended to be passive and less enthusiastic in learning to read.The teacherused letter card media and 
textbooks only, so students were less interested in learning, so that reading learning was not optimal.

The cause of low reading skills can be overcome with the use of thebig bookmedia.A bigbookisa large book measuring around $60 \times 50$ $\mathrm{cm}$ and usually contains pictures with beautiful colors.Bigger size of writings, as well as the availability of images in the media,willattract students to read.They have a higher curiosity towards the content of the reading presented in the media.They also feel more comfortable reading and not bored with the initial reading activities with the existence of thebig bookmedia.

Based on the background and problem stated, to improve the students' initial reading skills, researchers and teachers decide to apply thebig bookmediaas alearningaidthat can improve students' understanding, so that the initial reading skills are easy for students.

\section{METHODS}

This Classroom Action Research (CAR) aims to improve the initial reading skills of theme 8 about natural events in the second semester of the 2017/2018 academic year in Class IB of MI MuhammadiyahKedungJampang. There were 24 students as the research subjects consisting of 15 male students and 9 female students.

Data collection techniques in this study consisted of test and non-test techniques.Test techniques were in the form of five evaluation questions that aimed to find out students' learning achievement.The non-test technique used in this study wasin the form of preliminary reading skills assessment, teacher activity observation, and student activity observation. This research was carried out in two cycles and used the Kemmis and Mc. Taggart CAR model. Kemmis and Mc.Taggart (1982: 8), suggests the implementation of classroom action research includes four steps: planning, acting, observing, and reflecting.

The success criterion in this study was marked by the increase in the process and results of the initial reading learning in Class IB of MIM KedungJampang. The learning will be considered as successful if $80 \%$ of students complete the $K K M$ (Minimum Completeness Criteria). The $K K M$ in the initial reading skills of IndonesianLanguage subject in Class IB of MI Muhammadiyah Kedung Jampang is 70 .

\section{RESULTS AND DISCUSSION}

The discussion on this classroom action research is based on the results of cycle I and cycle II. Discussion on the results of the study can be explained as follows:

\section{The Improvement of Initial Reading Skill}

The results of research that has been carried out on theme 8 about Natural Events through the mediabig bookin cycle I and cycle II can be seen in table 4.7 below:

Table 2. The Improvement of Initial Reading Skill

\begin{tabular}{|c|c|c|c|}
\hline No & Cycle & Average & Criteria \\
\hline 1 & I & 2.42 & Moderate \\
\hline 2 & II & 3.4 & Very Good \\
\hline
\end{tabular}

The improvement of the initial reading skills from cycle I to cycle II can be seen in figure 1 below.

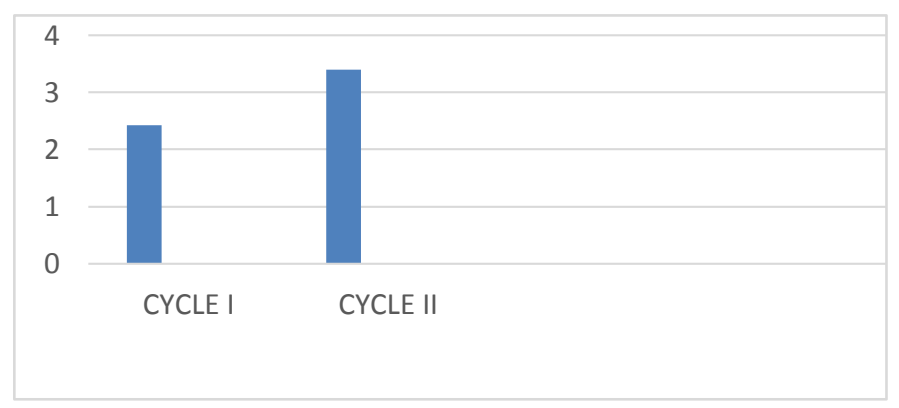

Figure 1. The Improvement of Initial Reading Skills

Based on the data in the table and graph above, it can be explained that the initial reading skills have increased from cycle I to cycle II. In the first cycle the average score of students' initial reading skills was 2.42 and categorized as moderate, while in the second cycle, the average score was 3.4 and categorized as very good. Thus, in the second cycle the students' initial reading skills increased significantly.

\section{The Improvement of Teacher Activity}

Based on the observation, teacher activity improves in every cycle. It is because the teacher taught the students in accordance withthe learning implementation plan compiled by the researcher.The improvement of teacher activity can be seen in Table 4.11.

Table 3. The Improvement of Teacher Activity

\begin{tabular}{|c|c|c|c|}
\hline No & Cycle & Average & Criteria \\
\hline 1 & I & 2.8 & Good \\
\hline 2 & II & 3.04 & Good \\
\hline
\end{tabular}

The improvement of teacher activity from cycle I to cycle II can be seen in Figure 2 below: 


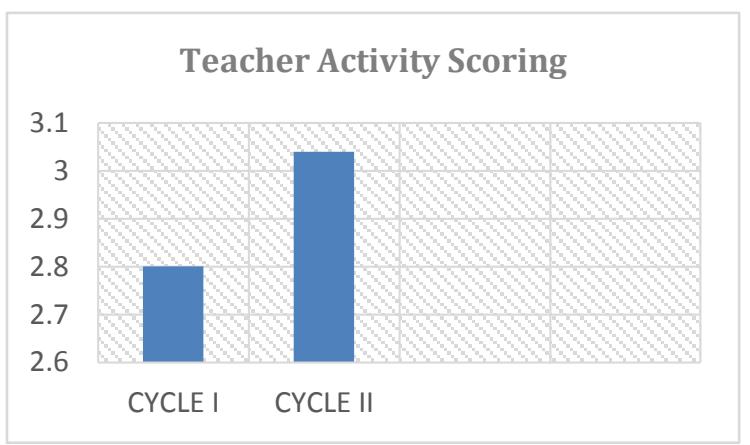

Figure 2. The Improvement of Teacher Activity

Based on Table 4.14 and Figure 4.6 above, it is revealed that the score of teacher activities increased fairly from cycle I to cycle II, which was from the average score of $2.8 \mathrm{in}$ good criteria to 3.04 in good criteria.Itindicated that at the time of the learning process from cycle I to cycle II there were improvements made by the teacher by looking at the results of reflection in cycle I, so that the research objectives can be achieved in cycle II.

\section{The Improvement of Student Activity}

Based on the observation conducted by observer 2 regarding student activities, the score can be explained in the following table:

Table 4. The Improvement of Student Activity

\begin{tabular}{|c|c|c|c|}
\hline No & Cycle & Average & Criteria \\
\hline 1 & I & 2.8 & Good \\
\hline 2 & II & 3.09 & Good \\
\hline \multicolumn{2}{|c|}{ The students' increased learning activities } \\
\hline
\end{tabular}
using the global method with the help of the big book mediacan be seen in Figure 3:

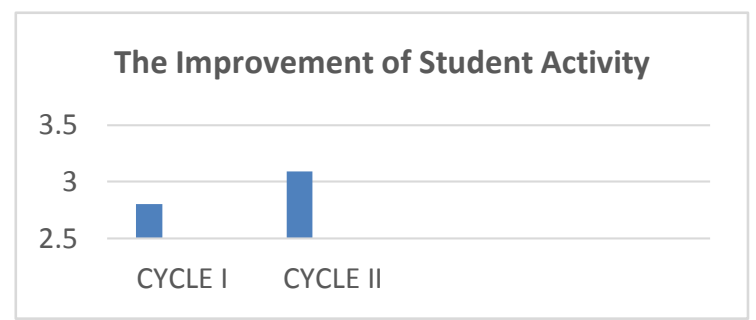

Figure 3. The Improvement of Student Activity

Based on the data in the table and graph above, it can be explained that student activity has increased from cycle I to cycle II. In cycle I the average score of student activity was 2.8 and categorized as good, whereas in cycle II, the average score was 3.09 and also in good criteria.So in the second cycle, the activities of students improved. The improvement was because students were involved in the learning process in the classroom.

\section{CONCLUSION}

Based on the results of research and discussion it can be concluded that theglobalmethodwith the assistance ofbig bookmediacan improve the initial reading skills and learning achievement of the first grade students of MI MuhammadiyahKedungJampang on the theme 8 about Natural Events with the following details:

1. Initial reading skills during the learning process using the global method with the assistance of the big book media from cycle I to cycle II have increased. The acquisition of completeness in cycle I was 2.42 in moderate criteria, while in cycle II it was 3.4 in very good criteria.

2. Student learning achievement in class IB of MI MuhammadiyahKedungJampang has increased from cycle I to cycle II, as evidenced by the average score in the first cycle was 73.3 with a completeness of $66.67 \%$. In the second cycle, the average score was 81.5 with $83.3 \%$ learning completeness.

Based on the research onclassroom action that has been carried out, theresearcher has several suggestions to be proposed, as follows:

1. The global method is a learning method that can increase students' initial reading activities; therefore researcher suggests a global method with the assistance of the big book media as an alternative in teaching students to read.

2. Teachers should modify thematic learning using the big book media, so that the learning is more effective and get maximum learning outcomes.

\section{REFERENCES}

Ahmadi, A \&Supriyono, W. 2013. PsikologiBelajar[Psychology of Learning].Jakarta: RinekaCipta.

Dalman. 2013. KeterampilanMembaca[Reading Skills]. Jakarta: PT Raja GrafindoPersada.

Kemmis, S \&McTaggart, R. 1982. The Action Research Planner.Victoria: Deakin University. 
Wahyuning, D. 2015. PenerapanMetodeMembaca Global untuk Meningkatkan

Kemampuan Membaca pada Mata Pelajaran Bahasa Indonesia Siswa Kelas I SDN 01 Semboro KabupatenJ ember [The Implementation of Global Reading
Method to Improve First Grade Students' Reading Skills in Indonesian Language Subject at SDN 01 Semboro, Jember Regency]. JurnalPancaran. 4; 59-68 